\title{
'Palmer' Mango Yield as Affected by Soil Class and Pedon Physicochemical Characteristics
}

\author{
Célia Lúcia Siqueira ${ }^{1}$, Moacir Brito Oliveira ${ }^{1}$, Karen Marcele de Jesus Silva ${ }^{1}$, Marcos Koiti Kondo ${ }^{1}$, \\ Renato Mendes de Oliveira ${ }^{1} \&$ Silvânio Rodrigues dos Santos ${ }^{1}$ \\ ${ }^{1}$ State University of Montes Claros, Janaúba, MG, Brazil \\ Correspondence: Célia Lúcia Siqueira, Department of Agrarian Sciences, State University of Montes Claros, \\ Janaúba, MG, Brazil. E-mail: clsiq@emater.mg.gov.br
}

Received: October 9, 2018

Accepted: January 9, 2019 Online Published: March 15, 2019

doi:10.5539/jas.v11n4p252

URL: https://doi.org/10.5539/jas.v11n4p252

The research is financed by FAPEMIG and CAPES.

\begin{abstract}
To evaluate the variation in 'Palmer' mango yield related to soil formation and soil physical and chemical properties, we studied a transect with 11 soil profiles, selected according to the altitude in a commercial orchard. Surface and subsurface diagnostic horizons were described up to two meters in depth. Soil depth, texture, structure, consistency, clay coating, cementation, and color of each horizon were morphologically determined. Undisturbed and disturbed samples were used to determine the soil total porosity, macroporosity, microporosity, density, saturated hydraulic conductivity, granulometry, total organic carbon, $\mathrm{pH}$, sum of bases, and the contents of $\mathrm{P}, \mathrm{S}, \mathrm{K}, \mathrm{Na}, \mathrm{Ca}, \mathrm{Mg}, \mathrm{Al}, \mathrm{Fe}, \mathrm{Mn}, \mathrm{Cu}$, and $\mathrm{Zn}$. The number of fruits (for production estimates), stem diameter, canopy area, and plant height were determined in four plants around each soil profile. Three classes of soil showed good suitability for mango cultivation: Argisol Red-Yellow Eutrophic typic, Cambisol Haplic Eutrophic $\mathrm{Tb}$, and Latosol Red Yellow Eutrophic typic. The 'Palmer' mango yield was correlated with the K contents, sum of bases, and $\mathrm{pH}$. The low yield was a result of the low $\mathrm{K}$ content associated with the presence of gravel.
\end{abstract}

Keywords: soil catena, soil horizon, Mangifera indica L.

\section{Introduction}

The mango tree (Mangifera indica L.) belongs to the family Anacardiaceae and is native to Asia, where $76 \%$ of world production is concentrated. India is the world's largest mango producer followed by Thailand (FAOSTAT, 2018). Brazil is among the largest producers and exporters of the fruit, and occupied, in 2016, the sixth and seventh position in the world rankings of mango production and exportation, respectively (Carvalho et al., 2017). The Northeast and Southeast regions, represented by the states of Bahia, Pernambuco, São Paulo, and Minas Gerais, are the main mango producers in Brazil (Treichel et al., 2016; Carvalho et al., 2017).

The cultivation of mango in northern Minas Gerais State represents $41 \%$ of the state's production (IBGE, 2016). 'Palmer'stands out as the predominant species, corresponding to $95 \%$ of the production in this region. The maintenance of its agricultural yield under irrigated systems is closely related to the chemical, physical, and biological attributes of the soil. These attributes are altered due to the continuous use of irrigation, fertilizers, pesticides, and machine traffic, which modify soil quality and, as a consequence, its productive potential (Corrêa et al., 2010).

Irrigation also changes several chemical attributes, such as $\mathrm{pH}$, cation exchange cationic capacity and exchangeable cations $\left(\mathrm{Ca}^{2+}, \mathrm{Mg}^{2+}, \mathrm{K}^{+}, \mathrm{Na}^{+}\right)$, micronutrients, and soil organic matter. Hence, the agricultural production is affected (Assis et al., 2010). In irrigated semiarid areas, such as the north of Minas Gerais, the mango tree has the potential to produce high-quality fruits at any time of the year by the use of the floral induction technology (Oliveira, 2015). However, high productions are directly associated with the physical and chemical quality of the soil and crop management practices, such as proper fertilization and irrigation. 


\section{Method}

\subsection{Description of the Experimental Site}

The study was carried out at Piranhas Farm belonging to the Gorutuba Project, in Janauba, MG, Brazil $\left(15^{\circ} 45^{\prime} 09^{\prime \prime} \mathrm{S}\right.$ and $\left.43^{\circ} 20^{\prime} 34^{\prime \prime} \mathrm{W}, 500 \mathrm{~m}\right)$. The climate of the region is considered as AW (tropical with dry winter), according to the Köppen classification, with mean temperature above $18{ }^{\circ} \mathrm{C}$ in the coldest month. Mean annual climate elements values are: precipitation of $873.5 \mathrm{~mm}$, temperature of $24.7^{\circ} \mathrm{C}$, and relative humidity of $65 \%$. The study was performed in a 23-ha area cultivated with 'Palmer' mango for ten years and previously cultivated with banana.

The irrigation consisted of a micro-sprinkler system with a flow rate of $75 \mathrm{~L} \mathrm{~h}^{-1}$ and lateral lines of $45 \mathrm{~m}$ in length. Sprinklers were spaced $8 \mathrm{~m}$ between rows and $5 \mathrm{~m}$ between plants. The nutritional reposition was based on leaf and soil analyses and carried out twice a year, right after harvest and before flowering. Monoammonium phosphate (MAP), potassium chloride, magnesium sulfate, and ammonium sulfate were used as sources of phosphorus $(\mathrm{P})$, potassium $(\mathrm{K})$, magnesium $(\mathrm{Mg})$, and nitrogen $(\mathrm{N})$, respectively. Liquid organic matter and fulvic and humic acids were also applied via soil at each fertilization event. Floral induction was performed from the third year of cultivation onwards aiming at offseason production.

\subsection{Experimental Design and Treatments}

The experiment consisted of a completely randomized design (CRD) with 11 soil profiles distributed across 23 ha crop from January to December 2014. The soil profiles were aligned in four rows with three profiles per row (except one row with two profiles). The soil profile was used to evaluate soil morphology, soil physical and chemical properties. The sampling position follows the toposequence position of the crop the toposequence position of the crop: shoulder, backslope, and footslope. A 2 m-deep trench was drilled in each soil profile to allow soil classification and the identification and measurement of the diagnostic horizons and layers. Each soil profile has three horizons (A, B, C) sampled, with a total of 33 soil horizons analyzed by disturbed and undisturbed soil samples.

\subsection{Evaluations}

Soil color, depth, structure, texture, clay coating, consistency, and cementation were morphologically determined in each horizon (Santos et al., 2013).

The central portions of the horizons $\mathrm{A}, \mathrm{B}$, and $\mathrm{C}$ were used for determining the chemical and physical attributes of the soil whereas the $\mathrm{BC}$ horizon was used for soil characterization and classification. Undisturbed soil samples were collected using a volumetric ring $(0.054 \mathrm{~m}$ height and $0.05 \mathrm{~m}$ internal diameter) to determine the soil total porosity (TP), microporosity, macroporosity, density $(\mathrm{SD})$, and saturated hydraulic conductivity $\left(\mathrm{K}_{\mathrm{sat}}\right)$ (Embrapa, 2011).

Disturbed soil samples were also taken from the same horizons and used for the evaluation of particle size distribution and chemical analysis for fertility purposes. The disturbed samples were air dried, ground, and sieved in a $2 \mathrm{~mm}$ mesh size. The samples were homogenized and used for granulometry analysis and to determine soil particle density (PD) (Embrapa, 2011); total organic carbon (TOC) (Yeomans \& Bremner, 1988); $\mathrm{pH}$ in water (1:2.5); extractable $\mathrm{P}$; exchangeable $\mathrm{S}, \mathrm{K}, \mathrm{Na}, \mathrm{Al}, \mathrm{Ca}$, and $\mathrm{Mg}$; and the contents of the micronutrients $\mathrm{Fe}, \mathrm{Mn}, \mathrm{Cu}$ and $\mathrm{Zn}$ (Embrapa, 2011). The exchangeable $\mathrm{Al}$ was extracted using a $1 \mathrm{~mol} \mathrm{~L}^{-1} \mathrm{KCl}$ solution and determined by titration with a $0.025 \mathrm{~mol} \mathrm{~L}^{-1} \mathrm{NaOH}$ solution. $\mathrm{Ca}$ and $\mathrm{Mg}$ were determined in the same extract by atomic absorption spectrophotometry. $\mathrm{P}, \mathrm{Na}, \mathrm{K}$, and the micronutrients were extracted with a Mehlich I solution $\left(0.05 \mathrm{~mol} \mathrm{~L}^{-1} \mathrm{HCl}+0.0125 \mathrm{~mol} \mathrm{~L}^{-1} \mathrm{H}_{2} \mathrm{SO}_{4}\right) . \mathrm{P}$ was determined by colorimetry $(660 \mathrm{~mm}$ wavelength $) ; \mathrm{K}$ and $\mathrm{Na}$ by flame photometry; micronutrients by atomic absorption spectrophotometry; and $\mathrm{S}$ by calorimetry.

Crop production characteristics, such as number of fruits per plant (used for production estimation), trunk diameter, canopy area, and plant height were evaluated in four plants (considered as plots) located around each trench. Since the mango tree yield stabilizes with plant age, management, and history of the area, the yield data of a single year was used.

\subsection{Statistical Analysis}

Soil data were subject to descriptive statistics and Pearson's correlation analysis with the crop production characteristics. Data were subject to analysis of variance and means were compared by the Tukey's test to differentiate the effect of the soil classes. 


\section{Results and Discussion}

The soils were classified according to Santos et al. (2013a), and three classes were identified: Argisol Red-Yellow Eutrophic tipic (PVAe), Cambisol Haplic Eutrophic Tb (CXbe), and Latosol Red-Yellow Eutrophic tipic (LVAe) (Table 1). Cambisols and Latosols predominated in the 11 soil profiles evaluated and presented five classes each.

Table 1. Morphological description of the horizons in soil profiles cultivated with 'Palmer' mango in the semiarid region of Minas Gerais State, Brazil

\begin{tabular}{|c|c|}
\hline \multicolumn{2}{|c|}{ Argisol Red-Yellow Eutrophic tipic1-PVAe1 } \\
\hline A & 0-0.22 m, subangular blocky, silty, weak, slightly hard, strong, reddish-brown (5YR 4/4) \\
\hline B & 0.22-0.45 m, subangular blocky, very fine clayey, weak, slightly hard,strong,reddish-yellow (5YR 4/6) \\
\hline $\mathrm{BC}$ & 0.45-0.63 m, subangular blocky, clayey, weak, hard,strong,reddish-yellow (5YR 5/8) \\
\hline $\mathrm{C}$ & 0.63-2.0 m+, subangular blocky, clayey, weak, slightly hard, strong, reddish-yellow (5YR 6/6) \\
\hline \multicolumn{2}{|c|}{ OBS: altitude $504.73 \mathrm{~m}$ asl, $3.20 \%$ declivity. } \\
\hline \multicolumn{2}{|c|}{ Cambisol Haplic Eutrophic Tb1-CXbel } \\
\hline A & 0-0.28 m, subangular blocky, medium, weak, slightly hard, moderate, dark reddish-brown (5YR 3/4) \\
\hline $\mathrm{Bi}$ & 0.28-0.55 m, subangular blocky, clayey, weak, hard, moderate, reddish-brown (5YR 4/4) \\
\hline $\mathrm{BC}$ & 0.55-0.68 m, subangular blocky, clayey, weak, hard, moderate, reddish-yellow (5YR 4/6) \\
\hline $\mathrm{C}$ & 0.68-2.0 m+, subangular blocky, clayey, weak, hard, moderate, reddish-yellow (5YR 4/6) \\
\hline \multicolumn{2}{|c|}{ OBS: altitude $500.09 \mathrm{~m}$ asl, $4.42 \%$ declivity, presence of nodules and tortuous roots. } \\
\hline \multicolumn{2}{|c|}{ Cambisol Haplic Eutrophic Tb2-CXbe2 } \\
\hline A & 0-0.28 m, subangular blocky, clayey, weak, hard, moderate, brown (7.5YR 4/4) \\
\hline $\mathrm{Bi}$ & 0.28-0.39 m, subangular blocky, clayey, weak, hard, moderate, strong brown (7.5YR 5/6) \\
\hline $\mathrm{BC}$ & 0.39-0.48 m, subangular blocky, clayey, weak, slightly hard, moderate, strong brown (7.5YR 5/6) \\
\hline $\mathrm{C}$ & 0.48-2.0 m+, subangular blocky, clayey, weak, slightly hard, moderate, strong brown (7.5YR 5/8) \\
\hline \multicolumn{2}{|c|}{ OBS: altitude $501.09 \mathrm{~m}$ asl, $1.37 \%$ declivity, presence of iron-manganese concretions. } \\
\hline \multicolumn{2}{|c|}{ Cambisol Haplic Eutrophic Tb3-CXbe3 } \\
\hline A & 0-0.20 m, subangular blocky, clayey, weak, hard, moderate,very dark gray (5YR 3/1) \\
\hline $\mathrm{Bi}$ & 0.20-0.40 m, subangular blocky, clayey, weak, very hard, moderate, dark reddish-brown (5YR 3/2) \\
\hline $\mathrm{BC}$ & 0.40-0.56 m, subangular blocky, clayey, weak, very hard, moderate, reddish-brown (5YR 5/3) \\
\hline $\mathrm{C}$ & 0.56-2.0 m+, subangular blocky, clayey, weak, hard, moderate, reddish-brown (5YR 5/4) \\
\hline \multicolumn{2}{|c|}{ OBS: altitude $502.11 \mathrm{~m}$ asl, $3.15 \%$ declivity, presence of iron-manganese concretions and gravel. } \\
\hline \multicolumn{2}{|c|}{ Cambisol Haplic Eutrophic Tb4-CXbe4 } \\
\hline A & 0-0.29 m, subangular blocky, clayey, weak, hard, moderate, dark reddish-brown (5YR 3/2) \\
\hline $\mathrm{Bi}$ & 0.29-0.62 m, subangular blocky, clayey, moderate, hard, moderate, reddish-brown (5YR 5/3) \\
\hline $\mathrm{C}$ & 0.62-2.0 m+, subangular blocky, clayey,weak, hard, moderate, reddish-brown(5YR 5/4) \\
\hline \multicolumn{2}{|c|}{ OBS: altitude $503.06 \mathrm{~m}$ asl, $0.53 \%$ declivity, presence of iron-manganese concretions and gravel. } \\
\hline \multicolumn{2}{|c|}{ Cambisol Haplic Eutrophic Tb5-CXbe5 } \\
\hline A & 0-0.18 m, subangular blocky, clayey, moderate, hard, moderate, dark brown (7.5YR 3/3) \\
\hline $\mathrm{Bi}$ & 0.18-0.43 m, subangular blocky, clayey, moderate, very hard, moderate, brown (7.5YR 4/3) \\
\hline $\mathrm{C}$ & 0.43-2.0 m+, subangular blocky, clayey, weak, hard, moderate, brown (7.5YR 4/4) \\
\hline \multicolumn{2}{|c|}{ OBS: altitude $503.53 \mathrm{~m}$ asl, $0.75 \%$ declivity. Moderately drained, presence of hydromorphicreduction mottlingandiron-manganese concretions. } \\
\hline \multicolumn{2}{|c|}{ Latosol Red-Yellow Eutrophic tipictípico 1-LVAe1 } \\
\hline A & 0-0.30 m, subangular blocky, clayey, weak, hard, weak,very dark grayish-brown (10YR 3/2) \\
\hline B & 0.30-0.80 m, subangular blocky, clayey, weak, hard, strong, brown (10YR 4/3) \\
\hline $\mathrm{C}$ & 0.80-2.0 m+, subangular blocky, clayey, weak, hard, strong, dark yellowish-brown (10YR 4/4) \\
\hline \multicolumn{2}{|c|}{ OBS: altitude $501.60 \mathrm{~m}$ asl, $0.64 \%$ declivity. } \\
\hline \multicolumn{2}{|c|}{ Latosol Red-Yellow Eutrophic tipic2_LVAe2 } \\
\hline A & 0-0.28 m, granular, clayey, weak, slightly hard, strong, very dark grayish-brown (10YR 3/2) \\
\hline Bw & 0.28-0.79 m, granular, clayey, weak, slightly hard, strong, yellowish-brown (10YR 5/6) \\
\hline $\mathrm{C}$ & 0.79-2.0 m+, granular, clayey, weak, hard,strong,yellowish-brown (10YR 5/6) \\
\hline \multicolumn{2}{|c|}{ OBS: altitude $504.19 \mathrm{~m}$ asl, $5.33 \%$ declivity. } \\
\hline \multicolumn{2}{|c|}{ Latosol Red-Yellow Eutrophic tipic3-LVAe3 } \\
\hline A & 0-0.27 m, granular, clayey, weak, slightly hard,weak,dark brown (10YR 3/3) \\
\hline $\mathrm{Bi}$ & 0.27-1.30 m, granular, clayey, weak, hard, strong, dark yellowish-brown (10YR 3/4) \\
\hline $\mathrm{BC}$ & 1.30-1.50 m, granular, clayey, weak, hard, strong, dark yellowish-brown (10YR 4/4) \\
\hline C & 1.50-2.0 m+, granular, clayey, weak, hard, strong, dark yellowish-brown (10YR 4/4) \\
\hline OBS & $504.24 \mathrm{~m}$ asl, $0.08 \%$ declivity, presence of iron-manganese concretions. \\
\hline
\end{tabular}




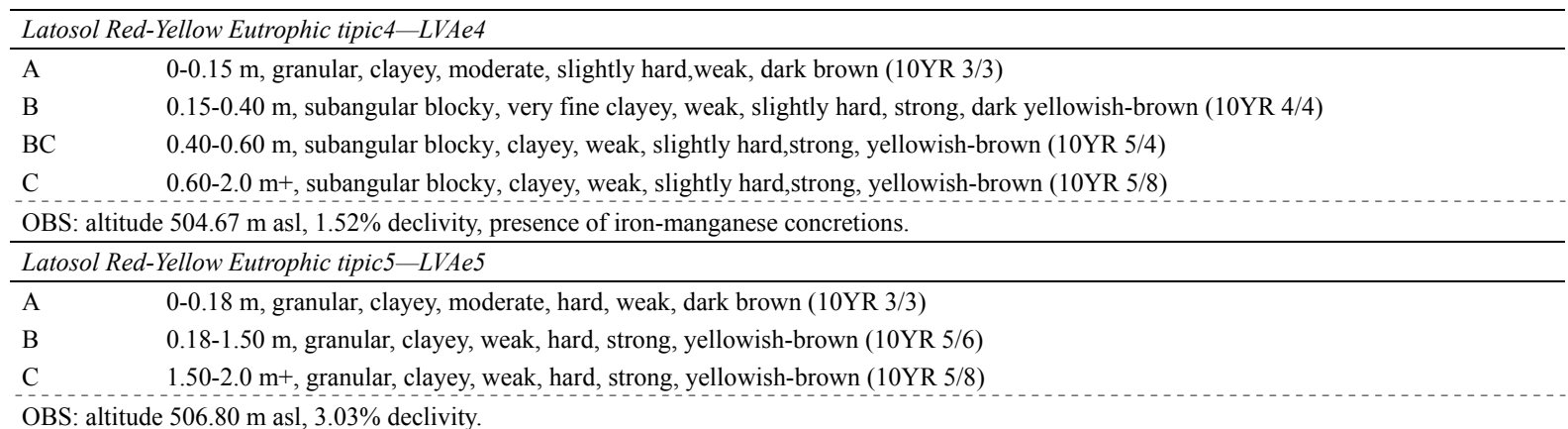

Note. Attributes described for each soil horizon: depth (m); structure; texture; clay coating; consistency; cementation, and color (dry).

CXbe1, CXbe2, and LVAe3 were observed in the lowest part of the landscape while the middle part was comprised exclusively by Cambisols (CXbe6, 7, 8). Latosols (LVAe4, 5, 10, 11) and PVAe9 were found in the highest portion of the landscape, with the prevalence of LVAe.

All soils in the area are derived from the weathering of meta-calcilutite and meta-calcarenite and present dominant clay levels (CODEMIG, 2012). Colluvial soils were observed in accumulation zones in the lower part of the landscape. This type of soil formation was predominantly calcareous and presented iron-manganese concretions. Cambisols (CXbe1, 6) occurred in the areas with the highest declivities.

The highest solum depth was observed in Latosol areas, with profiles presenting A + Bwhorizon up to $1.5 \mathrm{~m}$ thick. The lowest depth was verified in CXbe2 which showed a 0.39 m-thick A + Bi horizon. The subangular blocky structure prevailed in Argisols and Cambisols, with subangular blocky and granular structures in Latosols.

Soil moisture was similar in all profiles. Dry-soil consistency varied from slightly hard to hard; some Cambisol areas had a very hard consistency. Soil cementation was mainly weak (Latosols) and strong (Argisols) in the A, $\mathrm{B}$, and $\mathrm{C}$ horizons. Moderate cementation was recorded in all Cambisol horizons. The clayey texture predominated in all horizons, except in the horizons A (CXbe1 and PVAe1) and B (LVAe4). The latter was classified as very clayey texture. Soil clay coating was mostly weak; some clay coating was found in Cambisols and some areas of the A horizon in Latosols. The fragmented clay coatings are evidence of a transition of cambic to argillic horizons in Cambisols (Skorupa et al., 2017), and to Latosols, showed weak to moderate clay skins that representing the flocculation and immobilization of colloidal material enhanced by calcium ion, from calcareous materials of soil formation (Pal et al., 2003).

Similar characteristics were observed in clayey and very clayey texture Latosols as well as in Cambisols originated from pelitic rocks of the Bambui group, in the Curvelo-MG region (Pereira et al., 2010); and in Argisol in Pici, Fortaleza-CE (Mionet. et al., 2012). Careful management of the CXbe5 region was necessary because of the presence of gravel and a bad drainage spot. Additionally, iron-manganese nodules and concretions were commonly found in most parts of this area, indicating a high concentration of $\mathrm{Mn}$ in the soil (Table 2).

The frequent iron-manganese concretions are related to the soil parent material. Therefore, ferriferous quartz and ferric lenses are commonly found in limestone developed soils in the north of Minas Gerais. They tend to increase in size with depth in Cambisols and to remain small in Latosols (CODEMIG, 2012). Mn high values may be associated with elevated $\mathrm{pH}$ values. However, in this study, the Mn high values did not impair the 'Palmer' mango production.

The exploratory analysis of the soil attributes in each horizon is illustrated in Table 2. The mean and median values were similar in more than $61 \%$ of the attributes, with a distribution close to the central value. Most of the coefficients of variation of the attributes in $\mathrm{A}, \mathrm{B}$, and $\mathrm{C}$ horizons were medium and high, according to Warrick and Nielsen (1980). This high variability is related to the different soil classes and slope. Despite the variability of the attributes, yield was not reduced because of the increased fertilization and floral induction performed.

It means that crop management strategy with high of fertilizers associated with plant growth regulator can overcome original soil restrictions. 
Table 2. Descriptive statistics of soil attributes in the A, B, and C horizons of soils cultivated with 'Palmer' mango in the semiarid region of Minas Gerais State, Brazil

\begin{tabular}{|c|c|c|c|c|c|c|c|c|c|c|c|c|c|c|c|c|c|c|}
\hline \multirow{2}{*}{ Attribute } & \multicolumn{6}{|c|}{ Horizon A } & \multicolumn{6}{|c|}{ Horizon B } & \multicolumn{6}{|c|}{ Horizon $\mathrm{C}$} \\
\hline & Mean & Med & Max & Min & $\mathrm{CV}$ & W & Mean & Med & Max & Min & $\mathrm{CV}$ & W & Mean & Med & Max & Min & $\mathrm{CV}$ & W \\
\hline $\mathrm{pH}$ & 6.79 & 6.90 & 7.16 & 6.15 & 4.50 & $\mathrm{~N}$ & 6.67 & 6.87 & 7.06 & 6.04 & 5.65 & * & 6.49 & 6.57 & 7.00 & 5.31 & 7.72 & $\mathrm{~N}$ \\
\hline TOC & 1.94 & 1.97 & 2.62 & 1.36 & 18.66 & $\mathrm{~N}$ & 1.19 & 0.96 & 2.66 & 0.55 & 52.82 & $\mathrm{~N}$ & 1.58 & 1.72 & 2.29 & 0.65 & 41.11 & $\mathrm{~N}$ \\
\hline $\mathrm{P}$ & 8.31 & 9.19 & 16.23 & 2.64 & 46.44 & $\mathrm{~N}$ & 1.33 & 0.95 & 3.06 & 0.04 & 83.73 & $\mathrm{~N}$ & 1.67 & 1.36 & 2.85 & 0.39 & 45.88 & $\mathrm{~N}$ \\
\hline $\mathrm{S}$ & 5.30 & 5.01 & 9.80 & 1.87 & 44.92 & $\mathrm{~N}$ & 7.17 & 7.22 & 11.58 & 3.12 & 39.01 & $\mathrm{~N}$ & 9.71 & 8.84 & 17.73 & 4.40 & 48.24 & $\mathrm{~N}$ \\
\hline K & 184.48 & 215.25 & 255.75 & 48.00 & 39.32 & $*$ & 54.39 & 31.00 & 167.75 & 12.50 & 89.51 & * & 24.91 & 17.75 & 58.75 & 10.50 & 63.26 & $*$ \\
\hline $\mathrm{Na}$ & 0.28 & 0.23 & 0.87 & 0.16 & 72.79 & $*$ & 0.22 & 0.19 & 0.45 & 0.15 & 38.05 & * & 0.39 & 0.34 & 0.99 & 0.23 & 53.46 & $*$ \\
\hline $\mathrm{Ca}$ & 3.55 & 3.33 & 4.49 & 2.55 & 16.35 & $\mathrm{~N}$ & 3.31 & 3.30 & 5.29 & 1.24 & 36.72 & $\mathrm{~N}$ & 3.76 & 3.48 & 6.65 & 2.08 & 37.53 & $\mathrm{~N}$ \\
\hline $\mathrm{Mg}$ & 1.06 & 1.05 & 1.35 & 0.81 & 17.44 & $\mathrm{~N}$ & 0.65 & 0.71 & 1.12 & 0.26 & 43.32 & $\mathrm{~N}$ & 0.62 & 0.59 & 1.19 & 0.12 & 67.90 & $\mathrm{~N}$ \\
\hline $\mathrm{Al}$ & 0.00 & 0.00 & 0.01 & 0.00 & 171.27 & $*$ & 0.00 & 0.00 & 0.01 & 0.00 & 138.74 & $*$ & 0.03 & 0.01 & 0.21 & 0.00 & 204.56 & $*$ \\
\hline SB & 5.36 & 5.22 & 7.31 & 3.88 & 16.92 & $\mathrm{~N}$ & 4.32 & 4.57 & 6.53 & 2.23 & 28.98 & $\mathrm{~N}$ & 4.82 & 4.94 & 7.97 & 2.54 & 31.95 & $\mathrm{~N}$ \\
\hline $\mathrm{Fe}$ & 28.97 & 19.47 & 56.82 & 9.95 & 63.52 & $*$ & 37.53 & 28.24 & 93.95 & 18.07 & 57.98 & * & 54.27 & 50.53 & 91.15 & 23.64 & 46.48 & $\mathrm{~N}$ \\
\hline $\mathrm{Mn}$ & 34.47 & 12.01 & 83.00 & 5.94 & 93.18 & $*$ & 14.43 & 14.76 & 25.59 & 6.00 & 43.85 & $\mathrm{~N}$ & 8.50 & 7.57 & 13.98 & 4.60 & 35.12 & $\mathrm{~N}$ \\
\hline $\mathrm{Cu}$ & 1.03 & 1.07 & 1.56 & 0.37 & 34.36 & $\mathrm{~N}$ & 0.59 & 0.61 & 1.23 & -0.07 & 62.47 & $\mathrm{~N}$ & 0.64 & 0.63 & 1.10 & 0.16 & 54.31 & $\mathrm{~N}$ \\
\hline $\mathrm{Zn}$ & 13.32 & 14.25 & 17.22 & 8.64 & 26.24 & $*$ & 5.92 & 5.77 & 11.45 & 2.08 & 56.25 & $\mathrm{~N}$ & 1.98 & 2.14 & 3.64 & -0.42 & 57.79 & $\mathrm{~N}$ \\
\hline Sand & 25.50 & 28.22 & 34.74 & 6.75 & 34.47 & $*$ & 21.70 & 21.93 & 26.11 & 15.76 & 13.03 & $\mathrm{~N}$ & 20.76 & 20.59 & 27.91 & 13.22 & 19.92 & $\mathrm{~N}$ \\
\hline Silt & 34.72 & 30.55 & 56.80 & 24.63 & 30.41 & $*$ & 27.40 & 30.14 & 37.61 & 6.20 & 32.11 & $*$ & 28.59 & 29.08 & 36.50 & 18.41 & 17.81 & $\mathrm{~N}$ \\
\hline Clay & 39.78 & 39.10 & 47.15 & 33.30 & 10.81 & $\mathrm{~N}$ & 50.90 & 47.05 & 74.60 & 41.80 & 19.09 & $*$ & 50.66 & 51.60 & 61.00 & 42.50 & 10.46 & $\mathrm{~N}$ \\
\hline PD & 2.59 & 2.63 & 2.74 & 2.27 & 5.08 & $\mathrm{~N}$ & 2.67 & 2.67 & 2.90 & 2.25 & 6.97 & $\mathrm{~N}$ & 2.67 & 2.67 & 2.78 & 2.56 & 2.69 & $\mathrm{~N}$ \\
\hline TP & 0.44 & 0.44 & 0.53 & 0.34 & 12.23 & $\mathrm{~N}$ & 0.43 & 0.42 & 0.49 & 0.34 & 11.09 & $\mathrm{~N}$ & 0.45 & 0.46 & 0.51 & 0.41 & 6.14 & $\mathrm{~N}$ \\
\hline Macro & 0.11 & 0.13 & 0.20 & 0.03 & 44.75 & $\mathrm{~N}$ & 0.09 & 0.09 & 0.13 & 0.01 & 40.69 & $\mathrm{~N}$ & 0.10 & 0.09 & 0.14 & 0.06 & 22.73 & $\mathrm{~N}$ \\
\hline Micro & 0.33 & 0.33 & 0.35 & 0.30 & 5.20 & $\mathrm{~N}$ & 0.34 & 0.33 & 0.38 & 0.30 & 7.13 & $\mathrm{~N}$ & 0.35 & 0.35 & 0.41 & 0.27 & 10.67 & $\mathrm{~N}$ \\
\hline SD & 1.52 & 1.52 & 1.67 & 1.26 & 7.06 & $\mathrm{~N}$ & 1.54 & 1.53 & 1.72 & 1.40 & 6.09 & $\mathrm{~N}$ & 1.56 & 1.53 & 1.84 & 1.46 & 7.29 & $*$ \\
\hline $\mathrm{K}_{\text {sat }}$ & 24.24 & 18.57 & 53.51 & 2.29 & 85.94 & $*$ & 22.41 & 14.39 & 47.49 & 7.95 & 57.45 & $\mathrm{~N}$ & 34.54 & 35.73 & 42.35 & 13.80 & 23.99 & $*$ \\
\hline
\end{tabular}

Note. Med: median; Max: maximum; Min: minimum; CV: coefficient of variation (\%); W: Shapiro-Wilk test (*, $\mathrm{N}$ : non-normal and normal distribution at $5 \%$, respectively); $\mathrm{pH}$ in water; TOC: total organic carbon $\left(\mathrm{dag} \mathrm{kg}^{-1}\right)$; $\mathrm{P}, \mathrm{S}, \mathrm{K}, \mathrm{Na}, \mathrm{Fe}, \mathrm{Mn}, \mathrm{Cu}$, and $\mathrm{Zn}\left(\mathrm{mg} \mathrm{dm}^{-3}\right)$; $\mathrm{Ca}, \mathrm{Mg}, \mathrm{Al}$, and sum of bases (SB) $\left(\mathrm{cmol}_{\mathrm{c}} \mathrm{dm}^{-3}\right)$; sand, silt, and clay (\%); soil total porosity (TP), macroporosity (Macro), and microporosity (Micro) $\left(\mathrm{m}^{3} \mathrm{~m}^{-3}\right)$; soil density (SD) and particle density $(\mathrm{PD})\left(\mathrm{g} \mathrm{cm}^{-3}\right)$; saturated hydraulic conductivity $\left(\mathrm{K}_{\mathrm{sat}}\right)\left(\mathrm{cm} \mathrm{h}^{-1}\right)$.

Low (S), median (TOC, $\mathrm{P}, \mathrm{Fe}$, and $\mathrm{Cu}$ ), good ( $\mathrm{Ca}, \mathrm{Mg}$, and $\mathrm{SB}$ ), very good $(\mathrm{K})$, and high (pH, Mn, and $\mathrm{Zn}$ ) values were recorded for the chemical attributes of the A horizon (Table 2), as described by Ribeiro et al. (1999). This good soil fertility is a consequence of the fertilization performed to high yields in mango trees. However, soil properties range indicate soil fertility variability, but without yield changes, due to high and very high macronutrients levels.

Most of the soil horizons show $\mathrm{pH}$ values near-ideal range (5.5-6.8, Embrapa, 2004) to the mango tree. Special management attention to avoid the unavailability of some cationic micronutrients, which could be harmful to the crop (Novais et al., 2007).

Despite the good nutrient management of the soil, low levels of P were observed in the A horizon $\left(2.64 \mathrm{mg} \mathrm{dm}^{-3}\right)$ (Table 2) due to the tropical pedogenesis and intense weathering. As a result, $\mathrm{Fe}$ and $\mathrm{Al}$ oxides prevail in the soil and specifically adsorb P from the solution, thus making it unavailable to the plants (Novais et al., 2007).

Based on the visual diagnosis of the crop, the high Mn did not induce toxicity nor did it reduce the yield of 'Palmer' mango, this experiment did not find manganese toxicity symptoms by visual diagnosis, neither 'Palmer' mango yield decrease effect. According to Galliet al. (2009), most of the mango trees have a luxury absorption of $\mathrm{Mn}$ and show high levels of this element in the leaves, but no visual symptoms of toxicity are verified in the plants.

The texture of the soil was classified according to Santos et al. (2013b). The clayey texture was dominant in the soil morphological description and physical analysis (Tables 1 and 2) due to the limestone parent material, which favored the high levels of $\mathrm{Ca}$ and $\mathrm{Mg}$ and the formation of fertile soils. Therefore, complementary fertilization supported the approximate yields of $25 \mathrm{tha}^{-1}$ recorded in these soils. 
A physically ideal soilfor plant growthhas adequate water retention, aeration, heat supply, and low resistance to root growth. At the same time, good aggregate stability and soil water infiltration are critical physical conditions for the environmental quality of agroecosystems (Costa et al., 2016).

A mean value of $0.44 \mathrm{~m}^{3} \mathrm{~m}^{-3}$ was verified for TP in the soils studied (Table 2). An equal value was registered by Oliveira et al. (2015), in a fruit growing area in northern Minas Gerais. Conversely, Castro et al. (2009) recorded values of 0.56 and $0.54 \mathrm{~m}^{3} \mathrm{~m}^{-3}$ in Red Latosol under pasture and savanna conditions, respectively. These differences may probably be a result of soil compaction caused by the traffic of people, animals, and agricultural machinery, which interfere with soil structure, increasing SD and reducing TP (Klaus \& Timm, 2004; Becerra et al., 2010). In this study, the mean macroporosity value was $0.10 \mathrm{~m}^{3} \mathrm{~m}^{-3}$, similar to that registered in pastures (Carneiro et al., 2009). However, macroporosity in $\mathrm{A}\left(0.03 \mathrm{~m}^{3} \mathrm{~m}^{-3}\right)$ and $\mathrm{B}\left(0.007 \mathrm{~m}^{3} \mathrm{~m}^{-3}\right)$ horizons were very low in LVAe2 (Table 3), associated to intense machine traffic in the orchard, harm macropores keeping and compromising soil aeration and drainage because soil macroporosity is closely linked to soil hydraulic conductivity. However, macroporosity values were very low in the horizons A $\left(0.03 \mathrm{~m}^{3} \mathrm{~m}^{-3}\right)$ and B $\left(0.007 \mathrm{~m}^{3} \mathrm{~m}^{-3}\right)$ in LVAe2 (Table 3) probably due to the intensive use of agricultural machinery. As a consequence, the maintenance of macropores was impaired,and soil aeration and drainage was compromised since macroporosity is closely related to soil $\mathrm{K}_{\mathrm{sat}}$.

Table 3. Physical characterization of 11 soil profiles cultivated with 'Palmer' mango in the semiarid region of Minas Gerais State, Brazil. Total porosity (TP), macroporosity (Macro), microporosity (Micro), soil density (SD), and saturated hydraulic conductivity $\left(\mathrm{K}_{\mathrm{sat}}\right)$

\begin{tabular}{|c|c|c|c|c|c|c|}
\hline Soil & Horizon & $\mathrm{TP}$ & Macro & Micro & $\mathrm{SD}$ & $\mathrm{K}_{\text {sat }}$ \\
\hline & & - ------. & $\mathrm{m}^{3} \mathrm{~m}^{-}$ & --"--"-------- & $\mathrm{g} \mathrm{cm}^{-3}$ & $\mathrm{~cm} \mathrm{~h}^{-1}$ \\
\hline \multirow[t]{3}{*}{ PVAe } & A & 0.5015 & 0.1993 & 0.3022 & 1.26 & 42.49 \\
\hline & $\mathrm{B}$ & 0.4059 & 0.0771 & 0.3288 & 1.56 & 14.39 \\
\hline & $\mathrm{C}$ & 0.4355 & 0.0926 & 0.3429 & 1.55 & 41.77 \\
\hline \multirow[t]{3}{*}{ CXbe1 } & A & 0.5320 & 0.1837 & 0.3483 & 1.56 & 53.51 \\
\hline & $\mathrm{B}$ & 0.3976 & 0.0664 & 0.3312 & 1.72 & 27.85 \\
\hline & $\mathrm{C}$ & 0.4662 & 0.0913 & 0.3749 & 1.84 & 35.73 \\
\hline \multirow[t]{3}{*}{ CXbe2 } & A & 0.3962 & 0.0688 & 0.3274 & 1.67 & 52.46 \\
\hline & $\mathrm{B}$ & 0.4668 & 0.1329 & 0.3339 & 1.50 & 13.90 \\
\hline & $\mathrm{C}$ & 0.4290 & 0.0916 & 0.3374 & 1.53 & 34.37 \\
\hline \multirow[t]{3}{*}{ CXbe3 } & A & 0.4297 & 0.0895 & 0.3402 & 1.49 & 33.48 \\
\hline & $\mathrm{B}$ & 0.3660 & 0.0583 & 0.3077 & 1.59 & 12.93 \\
\hline & $\mathrm{C}$ & 0.4729 & 0.0616 & 0.4113 & 1.70 & 27.10 \\
\hline \multirow[t]{3}{*}{ CXbe4 } & A & 0.4710 & 0.1345 & 0.3366 & 1.63 & 3.75 \\
\hline & $\mathrm{B}$ & 0.4854 & 0.1220 & 0.3634 & 1.40 & 13.73 \\
\hline & $\mathrm{C}$ & 0.5058 & 0.1144 & 0.3914 & 1.52 & 42.35 \\
\hline \multirow[t]{3}{*}{ CXbe 5} & A & 0.4418 & 0.1269 & 0.3149 & 1.60 & 4.89 \\
\hline & $\mathrm{B}$ & 0.4403 & 0.1022 & 0.3381 & 1.53 & 47.49 \\
\hline & $\mathrm{C}$ & 0.4221 & 0.0892 & 0.3329 & 1.61 & 40.55 \\
\hline \multirow[t]{3}{*}{ LVAe1 } & A & 0.4558 & 0.1274 & 0.3284 & 1.50 & 18.57 \\
\hline & B & 0.4209 & 0.1248 & 0.2961 & 1.57 & 32.74 \\
\hline & $\mathrm{C}$ & 0.4118 & 0.1448 & 0.2670 & 1.46 & 32.07 \\
\hline \multirow[t]{3}{*}{ LVAe2 } & A & 0.3373 & 0.0335 & 0.3038 & 1.55 & 2.29 \\
\hline & $\mathrm{B}$ & 0.3376 & 0.0073 & 0.3302 & 1.63 & 7.95 \\
\hline & $\mathrm{C}$ & 0.4627 & 0.1220 & 0.3407 & 1.53 & 13.80 \\
\hline \multirow[t]{3}{*}{ LVAe3 } & A & 0.4085 & 0.0622 & 0.3463 & 1.52 & 42.32 \\
\hline & $\mathrm{B}$ & 0.4213 & 0.0917 & 0.3297 & 1.48 & 12.75 \\
\hline & $\mathrm{C}$ & 0.4568 & 0.1030 & 0.3537 & 1.50 & 34.07 \\
\hline \multirow[t]{3}{*}{ LVAe4 } & A & 0.4219 & 0.0880 & 0.3339 & 1.51 & 5.50 \\
\hline & B & 0.4669 & 0.0903 & 0.3766 & 1.51 & 23.43 \\
\hline & $\mathrm{C}$ & 0.4811 & 0.1215 & 0.3596 & 1.47 & 40.32 \\
\hline \multirow[t]{3}{*}{ LVAe5 } & A & 0.4882 & 0.1359 & 0.3523 & 1.49 & 7.41 \\
\hline & B & 0.4766 & 0.1120 & 0.3646 & 1.41 & 39.34 \\
\hline & $\mathrm{C}$ & 0.4574 & 0.0813 & 0.3760 & 1.50 & 37.79 \\
\hline
\end{tabular}

Note. 'Palmer' mango yield was correlated with soil $\mathrm{pH}(0.599, \mathrm{p}<0.05), \mathrm{K}$ content $(0.834, \mathrm{p}<0.01)$, and SB $(0.598, \mathrm{p}<0.05)$ in the A horizon. 
Most chemical attributes showed lower mean values in the horizons B and C, as a result of the low management influence in the deeper layers of soil (Correa et al., 2010). The soil parent material increased the levels of Ca and $\mathrm{Fe}$ in depth, while $\mathrm{S}$ was translocated to the subsurface.

Regarding the two dominant soil classes in the area, differences among Cambisols were found for $\mathrm{pH}$, sand, and clay; and differences among Latosols were identified for $\mathrm{pH}, \mathrm{Na}, \mathrm{Mg}$, clay, and micropores (Table 4).

Table 4. Chemical and physical attributes of Cambisol and Latosol profiles cultivated with 'Palmer' mango in the semiarid region of Minas Gerais State, Brazil

\begin{tabular}{|c|c|c|c|c|c|c|c|}
\hline Soil class & $\mathrm{pH}$ & $\mathrm{Na}$ & $\mathrm{Mg}$ & Sand & Silt & Clay & Micropores \\
\hline & & \multicolumn{2}{|c|}{------ $\mathrm{cmol}_{\mathrm{c}} \mathrm{dm}^{-3}$} & \multicolumn{3}{|c|}{ 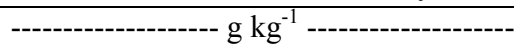 } & $\mathrm{m}^{3} \mathrm{~m}^{-3}$ \\
\hline CXbe1 & $6.56 \mathrm{~b}$ & $0.36 \mathrm{a}$ & $0.83 \mathrm{a}$ & $268.0 \mathrm{a}$ & $313.2 \mathrm{a}$ & $418.8 b$ & $0.35 \mathrm{a}$ \\
\hline CXbe2 & $6.85 \mathrm{ab}$ & $0.34 \mathrm{a}$ & $0.52 \mathrm{a}$ & $232.9 \mathrm{ab}$ & $323.4 \mathrm{a}$ & $443.7 b$ & $0.33 \mathrm{a}$ \\
\hline CXbe3 & $6.63 b$ & $0.44 \mathrm{a}$ & $0.72 \mathrm{a}$ & $238.2 \mathrm{ab}$ & $310.3 \mathrm{a}$ & $451.5 \mathrm{ab}$ & $0.35 \mathrm{a}$ \\
\hline CXbe4 & $6.07 \mathrm{c}$ & $0.23 \mathrm{a}$ & $0.93 \mathrm{a}$ & $179.0 \mathrm{~b}$ & $304.0 \mathrm{a}$ & $517.0 \mathrm{a}$ & $0.36 \mathrm{a}$ \\
\hline CXbe5 & $7.00 \mathrm{a}$ & $0.23 \mathrm{a}$ & $0.95 \mathrm{a}$ & $252.7 \mathrm{ab}$ & $295.5 a$ & $451.8 \mathrm{ab}$ & $0.36 \mathrm{a}$ \\
\hline CV $(\%)$ & 1.86 & & & 12.50 & & 5.63 & \\
\hline LVAe1 & $6.98 \mathrm{a}$ & $0.28 \mathrm{a}$ & $0.65 \mathrm{bc}$ & $219.6 \mathrm{a}$ & $382.1 \mathrm{a}$ & $398.3 b$ & $0.30 \mathrm{~b}$ \\
\hline LVAe 2 & $6.86 \mathrm{a}$ & $0.22 \mathrm{ab}$ & $0.40 \mathrm{c}$ & $213.2 \mathrm{a}$ & $335.6 \mathrm{a}$ & $451.2 \mathrm{ab}$ & $0.32 \mathrm{ab}$ \\
\hline LVAe 3 & $6.44 \mathrm{ab}$ & $0.27 \mathrm{a}$ & $0.45 b c$ & $248.2 \mathrm{a}$ & $285.1 \mathrm{a}$ & $466.7 \mathrm{ab}$ & $0.34 \mathrm{ab}$ \\
\hline LVAe 4 & $6.77 \mathrm{a}$ & $0.22 \mathrm{ab}$ & $1.14 \mathrm{a}$ & $226.2 a$ & $235.5 \mathrm{a}$ & $538.3 \mathrm{a}$ & $0.35 \mathrm{ab}$ \\
\hline LVAe 5 & $5.96 a$ & $0.20 \mathrm{~b}$ & $0.79 \mathrm{ab}$ & $258.9 \mathrm{a}$ & $240.4 \mathrm{a}$ & $500.7 \mathrm{ab}$ & $0.36 \mathrm{a}$ \\
\hline $\mathrm{CV}(\%)$ & 3.92 & 9.36 & 18.58 & & & 10.27 & 6.61 \\
\hline
\end{tabular}

Note. Means followed by the same letter in the column do not differ by the Tukey's test $(\mathrm{p}<0.05)$.

No differences between soil classes were observed for trunk diameter and canopy area. However, differences were detected for plant height and yield. 'Palmer' mango yield varied from 19.66 to $31.35 \mathrm{t} \mathrm{ha}^{-1}$, similarly to the $31.06 \mathrm{t} \mathrm{ha}^{-1}$ reported by Campos et al. (2008) in mango trees under different irrigation levels.

Table 5. Trunk diameter, plant height, canopy area, and yield in 'Palmer' mango cultivated in the semiarid region of Minas Gerais State, Brazil

\begin{tabular}{lllll}
\hline Soil class & Trunk diameter & Plant height & Canopy area & Yield \\
\hline & $-0 .-0-17 \mathrm{a}$ & $2.58 \mathrm{~b}$ & $6.65 \mathrm{a}$ & $\mathrm{t} \mathrm{ha}^{-1}$ \\
PVAe & $0.17 \mathrm{a}$ & $6.60 \mathrm{a}$ & $22.01 \mathrm{a}$ \\
CXbe1 & $0.17 \mathrm{a}$ & $2.99 \mathrm{a}$ & $7.27 \mathrm{a}$ & $22.84 \mathrm{~b}$ \\
CXbe2 & $0.17 \mathrm{a}$ & $3.33 \mathrm{a}$ & $6.49 \mathrm{a}$ & $19.66 \mathrm{~b}$ \\
CXbe3 & $0.16 \mathrm{a}$ & $2.59 \mathrm{~b}$ & $5.54 \mathrm{a}$ & $25.99 \mathrm{~b}$ \\
CXbe4 & $0.16 \mathrm{a}$ & $2.55 \mathrm{~b}$ & $8.20 \mathrm{a}$ & $29.01 \mathrm{a}$ \\
CXbe5 & $0.19 \mathrm{a}$ & $3.14 \mathrm{a}$ & $7.41 \mathrm{a}$ & $22.70 \mathrm{~b}$ \\
LVAe1 & $0.18 \mathrm{a}$ & $3.28 \mathrm{a}$ & $5.04 \mathrm{a}$ & $25.58 \mathrm{~b}$ \\
LVAe2 & $0.17 \mathrm{a}$ & $2.75 \mathrm{~b}$ & $5.85 \mathrm{a}$ & $31.35 \mathrm{a}$ \\
LVAe3 & $0.17 \mathrm{a}$ & $2.65 \mathrm{~b}$ & $5.96 \mathrm{a}$ & $30.53 \mathrm{a}$ \\
LVAe4 & $0.17 \mathrm{a}$ & $2.78 \mathrm{~b}$ & $7.61 \mathrm{a}$ & $21.67 \mathrm{~b}$ \\
LVAe5 & $0.18 \mathrm{a}$ & $2.80 \mathrm{~b}$ & $\mathrm{~m}$ & \\
\hline
\end{tabular}

Note. Means followed by the same letter in the column do not differ by the Tukey's test $(\mathrm{p}<0.05)$.

Due to cropping orchard time, size and plant shape is influenced mainly by pruning, which is frequent in the management system of 'Palmer' mango. This fact shows that this small variation in tree size is not a determinant factor of yield. None of the plant characteristics evaluated showed a positive correlation with yield. The diameter of the trunk was the only trait that significantly correlated with yield $(0.349 ; p<0.05)$.

The lowest yields were observed in Cambisol (CXbe1, 2, 3, 4) and Latosol (LVAe1, 5, 2) profiles. CXbe3was characterized by its low depth, presence of gravel, and the lowest $\mathrm{K}$ contents $\left(50.83 \mathrm{mg} \mathrm{dm}^{-3}\right)$ in the profile. 
These conditions impaired the development of the characteristic deep root system since mango trees require no physical or chemical impediment in the soil for full production. The importance of $\mathrm{K}$ is highlighted by Costa et al. (2011) in 'Tommy Atkins' mango fertilization.

The second lowest yield was identified in LVAe5. Although it is a deep soil (Table 1), LVAe5 presented low levels of $\mathrm{K}\left(33.17 \mathrm{mg} \mathrm{dm}{ }^{-3}\right), \mathrm{S}\left(7.42 \mathrm{mg} \mathrm{dm}^{-3}\right)$, and sum of bases $\left(3.23 \mathrm{cmol}_{\mathrm{c}} \mathrm{dm}^{-3}\right)$, which directly influenced plant yield. CXbe1 and CXbe3 showed low chemical fertility, andsoil physical conditions were not the most favorable for mango cultivation since it presented iron-manganese concretions, gravel, and tortuous roots. However, the recorded low yields were higher than the national mean of $15.63 \mathrm{t} \mathrm{ha}^{-1}$. These results indicate that although some soil profiles had low physicochemical quality, they are suitable for mango production (Poll et al. 2012).

The highest yields were identified in PVAe, CXbe5, LVAe3, and LVAe4. Adequate soil structure and depth were observed in Latosols (Table 1), in addition to the highest values of $\mathrm{K}\left(249.5\right.$ and $\left.255.75 \mathrm{mg} \mathrm{dm}^{-3}\right)$ and SB (4.96 and $5.06 \mathrm{cmol}_{\mathrm{c}} \mathrm{dm}^{-3}$ ) in the A horizons from LVAe3 and LVAe4, respectively. Even though CXbe5 had no physical limitation, flooding conditions were indicated by the moderate to imperfect drainage in the description of the soil profile.

Despite the differences among the distinct LVAe, a mean yield of $26.37 \mathrm{t} \mathrm{ha}^{-1}$ was recorded, whereas CXbe showed a mean yield of $23.90 \mathrm{tha}^{-1}$.

\section{Conclusions}

Even under intensive production system, the eutrophic soils have high productive potential and suitability for the mango tree cultivation.

All soils presented iron-manganese concretions, but with no interference in the 'Palmer' mango yield.

The 'Palmer' mango yield is directly influenced by the soil $\mathrm{K}$ contents, $\mathrm{SB}$, and $\mathrm{pH}$, and it is impaired by the low effective depth and gravel presence in the soil profile.

\section{Acknowledgements}

The authors wish to acknowledge the Fundação de Amparo à Pesquisa do Estado de Minas Gerais-FAPEMIG, the Minas Gerais State Research Foundation and the Financiadora de Estudos e Projetos-FINEP, for the financial support and granting of subsidies.

This study was financed in part by the Coordenação de Aperfeiçoamento de Pessoal de Nível Superior-Brasil (CAPES)-Finance Code 001.

\section{References}

Assis, C. P., de Oliveira, T. S., da Nóbrega Dantas, J. D. A., \& de Sá Mendonça, E. (2010). Organic matter and phosphorus fractions in irrigated agroecosystems in a semi-arid region of Northeastern Brazil. Agriculture, Ecosystems \& Environment, 138(1), 74-82. https://doi.org/10.1016/j.agee.2010.04.002

Becerra, A. T., Botta, G. F., Bravo, X. L., Tourn, M., Melcon, F. B., Vazquez, J., \& Nardon, G. (2010). Soil compaction distribution under tractor traffic in almond (Prunus amigdalus L.) orchard in Almería España. Soil and Tillage Research, 107(1), 49-56. https://doi.org/10.1016/j.still.2010.02.001

Campos, J. D. C., Silva, V. D., Azevedo, P. D., Borges, C. J., Soares, J. M., Moura, M. D., \& Silva, B. D. (2008). Evapotranspiração e produtividade da mangueira sob diferentes tratamentos de irrigação. Revista Brasileira de Engenharia Agrícola e Ambiental, 12(2), 150-156. https://doi.org/10.1590/S1415-43662008000200007

Carneiro, M. A. C., Souza, E. D., Reis, E. F., Pereira, H. S., \& Azevedo, W. R. (2009). Atributos físicos, químicos e biológicos de solo de cerrado sob diferentes sistemas de uso e manejo. Revista Brasileira de Ciência do Solo, 33(1), 147-157. https://doi.org/10.1590/S0100-06832009000100016

Carvalho, C., Kist, B. B., Santos, C. E., Treichel, M., \& Filter, C. F. (2017). Anuário brasileiro da fruticultura 2017 (p. 88). Santa Cruz do Sul: Editora Gazeta Santa Cruz.

CODEMIG (Companhia de Desenvolvimento Econômico de Minas Gerais). (2012). Mapa geológico da folha de Janaúba Gerais, Brasil. Versão SIG.

Corrêa, R. M., Freire, M. B. G. S., Ferreira, R. L., Silva, J. A. A., Pessoa, L. G., Miranda, M. A., \& Melo, D. V. M. (2010). Atributos físicos de solos sob diferentes usos com irrigação no semiárido de Pernambuco. Revista Brasileira de Engenharia Agrícola e Ambiental, 14(4), 358-365. https://doi.org/10.1590/ S1415-43662010000400003 
Costa, M. E., Costa, A. V., de Souza, W. C. M., Gurgel, M. T., \& da Silva, R. M. (2011). Caracterização nutricional da mangueira 'Tommy Atkins' sob adubação potássica. Revista Verde, 6(2), 12130.

Costa, C. D. O., Alves, M. C., \& de Pádua Sousa, A. (2016). Armazenamento de água em dois solos sob diferentes usos e manejos. Revista de Ciências Ambientais, 10(2), 55. https://doi.org/10.18316/19818858.16 .31

Embrapa. (2004). Cultivo da mangueira (2nd ed.). Embrapa Semiárido, Sistemas de Produção 2, Versão Eletrônica.

Embrapa. (2011). Serviço Nacional de Levantamento e Conservação do Solo (p. 212). Manual de métodos de análise do solo. Brasília: Ministério da Agricultura.

FAOSTAT (Food and Agriculture Organization of the United Nations). (2018). Banco de dados. Roma: FAOSTAT.

Galli, J. A., Silveira, L. C. P., Michelotto, M. D. \& Martins, A. L. M. (2009). Avaliação da incidência de antracnose, do desempenho e estado nutricional de variedades de mangueira, para cultivo orgânico, na região centro-norte do estado de São Paulo. Revista Brasileira de Fruticultura, 31(3), 701-709. https://doi.org/10.1590/S0100-29452009000300012

IBGE. (2016). Levantamento Sistemático da Produção Agrícola. Rio de Janeiro: IBGE.

Klaus, R. \& Timm, L. C. (2004). Solo, planta e atmosfera: Conceitos, processos e aplicações (p. 478). Barueri: Manole.

Mionet, R. L., Nascimento, E. M. S., de Lima Sales, F. A., da Silva, S. F., Duarte, J. M. L., \& de Sousa, B. M. (2012). Variabilidade espacial da porosidade total, umidade e resistência do solo à penetração de um Argissolo amarelo. Revista Semina: Ciências Agrárias, 33(6), 2057-2066. https://doi.org/10.5433/ 1679-0359.2012v33n6p2057

Novais, R. F. (2007). Fertilidade do solo. Sociedade Brasileira de Ciência do Solo (pp. 276-374). Viçosa, MG.

Oliveira, R. T., Rocha, L. C. D., Rocha, I. G. \& de Lima Fiorillo, C. A. (2010). Caracterização física dos solos sob diferentes usos. Revista Agrogeoambiental, 2(1). https://doi.org/10.18406/2316-1817v2n12010246

Oliveira, M. B., Pereira, M. C. T., Mizobutsi, G. P., Maia, V. M., Silva, J. F., Oliveira, J. A. A., ... Mouco, M. A. C. (2015). Paclobutrazol and tippruning in the management of 'palmer' mango trees in the semi-arid region of Brazil. Revista Acta Horticulturae, 1075, 149-156. https://doi.org/10.17660/ActaHortic.2015.1075.16

Pal, D. K., Srivastava, P., \& Bhattacharyya, T. (2003). Clay illuviation in calcareous soils of the semiarid part of the Indo-Gangetic Plains, India. Geoderma, 115(3), 177-192. https://doi.org/10.1016/S0016-7061(02) $00377-4$

Pereira, T. T. C., Ker, J. C., Schaefer, C. E. G. R., Barros, N. D., Neves, J. C. L., \& Almeida, C. C. (2010). Gênese de Latossolos e Cambissolos desenvolvidos de rochas pelíticas do grupo Bambuí-Minas Gerais. Revista Brasileira de Ciência do Solo, 34(4), 1283-1295. https://doi.org/10.1590/S0100-0683201000 0400026

Poll, H., Kist, B. B., Santos, C. E., Reetz, E. R., Carvalho, C., \& Silveira, D. N. (2013). Anuário brasileiro da fruticultura (p. 136). Editora Gazeta Santa Cruz, Santa Cruz do Sul.

Ribeiro, A. C., Guimarães, P. T. G., \& Alvarez, V. H. V. (1999). Recomendações para uso de corretivos e fertilizantes em Minas Gerais (p. 359, $5^{\text {a }}$ Aproximação). Viçosa, MG, Comissão de Fertilidade do Solo do Estado de Minas Gerais-CFSEMG.

Santos, H. G. dos., Jacomine, P. K. T., Anjos, L. H. C., Oliveira, V. A., Lumbreras, J. F., Coelho, M. R., ... Oliveira, J. B. (2013a). Sistema brasileiro de classificação de solos (3rd ed., p. 353). Brasília, DF: Embrapa.

Santos, H. G., Jacomine, P. K. T., Anjos, L. H. C. dos., Oliveira, V. A. de., Lumbreras, J. F., Coelho, M. R., ... Cunha, T. J.F. (2018). Sistema brasileiro de classificação de solos (5th ed.). Brasília, DF: Embrapa.

Santos, R. D., Lemos, R. D., Santos, H. D., Ker, J. C., \& Anjos, L. D. (2013b). Manual de descrição e coleta de solo no campo (6th ed., p. 100). Viçosa: Sociedade Brasileira de Ciência do solo.

Skorupa, A. L. A., Silva, S. H. G., Poggere, G. C., Tassinari, D., Pinto, L. C., Zinn, Y. L., \& Curi, N. (2017). Similar Soils but Different Soil-Forming Factors: Converging Evolution of Inceptisols in Brazil. Pedosphere, 27(4), 747-757. https://doi.org/10.1016/S1002-0160(17)60443-0 
Treichel, M., Kist, B. B., Santos, C. E., Carvalho, C., \& Beling, R. R. (2016). Anuário brasileiro da fruticultura 2016 (p. 88). Santa Cruz do Sul: Editora Gazeta Santa Cruz.

Warrick, A. W., \& Nielsen, D. R. (1980). Spatial variability of soil physical properties in the field. In D. Hillel (Ed.), Applications of soil physics (pp. 319-344). New York, Academic Press. https://doi.org/10.1016/ B978-0-12-348580-9.50018-3

Yeomans, J. C., \& Bremner, J. M. A. (1988). Rapid and precise method for routine determination of organic carbon in soil. Communications in Soil Science and Plant Analysis, 19, 1467-1476. https://doi.org/10.1080/ 00103628809368027

\section{Copyrights}

Copyright for this article is retained by the author(s), with first publication rights granted to the journal.

This is an open-access article distributed under the terms and conditions of the Creative Commons Attribution license (http://creativecommons.org/licenses/by/4.0/). 